\title{
Ideology and Architecture in the Portuguese 'Estado Novo': Cultural Innovation within a Para-Fascist State (1932-1945)
}

\author{
Rita Almeida de Carvalho \\ Instituto de Ciências Sociais da Universidade de Lisboa \\ Funded by the Foundation for Science and Technology, \\ Portugal (SFRH/BPD/68725/2010) \\ rita.carvalho@ics.ulisboa.pt
}

\begin{abstract}
This article challenges the common assumption of the fascist nature of the Portuguese Estado Novo from the thirties to mid-forties, while recognizing the innovative, modernizing dynamic of much of its state architecture. It takes into account the prolix discourse of Oliveira Salazar, the head of government, as well as Duarte Pacheco's extensive activity as minister of Public Works, and the positions and projects of the architects themselves. It also considers the allegedly peripheral status of architectural elites, and the role played by decision makers, whether politicians or bureaucrats, in the intricate process of architectural renewal. The article shows that a non-radical form of nationalism has always prevailed as a discourse in which to express the unique Portuguese spirit, that of a people that saw itself as transporting Christian morality and faith across the world, a civilizing role that the country continued to fulfil in its overseas colonies. Taking the architectural legacy of the Estado Novo in its complexity leads to the conclusion that, while the dictatorship did not dismiss modernization outright, and though it adopted what could be superficially considered fascist traits, the language of national resurgence disseminated by the Portuguese regime did not express a future-oriented fascist ideology of radical rebirth. The country's futural orientation would be accomplished by adopting a restrained policy of moderate modernization that lacked the dynamism and utopian ambition of fascism, a conservatism reflected in its architecture.
\end{abstract}




\section{Keywords}

Portugal - architecture - fascism - para-fascism - Salazarism - modernism traditionalism

This article aims to contribute to the debate on the nature of interwar dictatorships and, more precisely, to ascertain whether the apparent embrace of fascism by the Portuguese Estado Novo [New State], from its inception in 1932 up to the aftermath of the Second World War, was an authentic one, reflected in the radicalness and innovation of state architecture. Was it a genuine variant of generic fascism or was it rather a simple emulation of the externals of fascist revolutionary regimes, and thus in the context of new buildings, prepared to adopt elements of Italian Fascism and Nazism ${ }^{1}$ without any commitment to a veritable 'national revolution'? Although some Portuguese historians recognize the existence of a Portuguese fascist regime, ${ }^{2}$ researchers in comparative fascist studies usually label the Portuguese New State as a conservative authoritarian, ${ }^{3}$ pseudo-fascist, fascistized or para-fascist regime. ${ }^{4}$ The latter argue that, after banishing the fascist National Syndicalists, the regime set about selectively borrowing some of fascism's features, such as the militia, youth movement, leader cult and so forth, a process that has been called 'political hybridization'.

1 This chapter follows Roger Griffin's argument that the Italian Fascism and Nazism were the only fully fascist regimes. See Roger Griffin, Modernism and Fascism: The Sense of a Beginning under Mussolini and Hitler (Basingstoke: Palgrave Macmillan, 2007).

2 Fernando Rosas, 'Le Salazarisme et L'homme nouveau : Essai sur L'État nouveau et la question du totalitarisme dans les années trente et quarante,' in L'Homme nouveau dans l'Europe fasciste (1922-1945), ed. Marie-Anne Matard-Bonucci and Pierre Milza (Paris: Fayard, 2004), 87-123; Luís Reis Torgal, 'Salazar and the Portuguese "New State”: Images and Interpretations,' Annual of Social History (Godišnjak za društvenu istoriju) 2 (2009): 7-18; Manuel de Lucena, 'Reflections on the Fall of the Salazarist Regime and on What Followed,' in Modern Europe after Fascism, 1943-1980, ed. Stein Ugelvik Larsen (Boulder: Social Science Monographs, 1998): $1636-1678$.

3 Among many others, Roger Griffin, The Nature of Fascism (London: Routledge, 1993); Stanley Payne, A History of Fascism, 1914-1945 (London: UCL Press, 1995); António Costa Pinto, Salazar's Dictatorship and European Fascism: Problems of Interpretation (New York: Columbia University Press, 1996); A. James Gregor, Phoenix: Fascism in Our Time (New Brunswick, Transaction Publishers, 1999); Juan J. Linz, Authoritarian and Totalitarian Regimes (Boulder: Lynne Rienner, 200o); Michael Mann, Fascists (Cambridge: Cambridge University Press, 2004); Robert O. Paxton, The Anatomy of Fascism (New York: Vintage Press, 2005); Roger Eatwell, 'Introduction: New Styles of Dictatorship and Leadership in Interwar Europe,' Totalitarian Movements and Political Religions 7, no. 2 (2006): 127-137; Arnd Bauerkämper, 'A New Consensus? Recent Research on Fascism in Europe, 1918-1945', History Compass 4, no. 3 (2006): $536-566$.

4 On the concept of para-fascism see Griffin, The Nature of Fascism, 120-124. 
Using this strategy, Salazarism found adequate weapons to fight against the excess of liberalism and, more importantly, to face the communist threat, both of which were seen as undermining national peace and its traditional social arrangements. At the same time, Salazar found a way to underline the difference separating his regime from the previous regime, a republican, parliamentary and anticlerical one. None of the comparative scholars consider that Salazarism was pursuing a Portuguese equivalent of a revolutionary national rebirth comparable to Italian Fascism and Nazism. However, this did not stop fascism from impacting the regime, sometimes blurring the distinction in cultural practice between fascistized authoritarianism and fascism. ${ }^{5}$

Architecture and urban planning are reliable sources for the study of political systems. As Walter Gropius argued, 'the outwards forms of the New Architecture ... are ... simply the inevitable logical product of the intellectual, social and technical conditions of our age. ${ }^{6}$ Going beyond their existence as material 'objects' and creative expression, architecture and urban planning will be explored here in their multiple meanings, from building and design processes to construction, taking into account professional interactions, decision-making processes, but also architectural discourses, perceptions and experience. ${ }^{7}$ But the analysis will focus on the role of public buildings in satisfying the regime's need for legitimacy and social cohesion rather than concentrating on its formal or aesthetic aspects.

Since this research is focused on the insights afforded by the built environment to resolve the issue of the New State's relationship to fascism, the concept of fascist architecture and urban planning should be explained. What makes them unique is their capacity to go beyond instilling fear, belligerence,

5 António Costa Pinto, The Nature of Fascism revisited (New York, NY: Columbia University Press, 2012); Aristotle Kallis, "Fascism", "Para-fascism" and "Fascistization": On the Similarities of Three Conceptual Categories,' European History Quarterly 33, no. 2 (2003): 219-250.

6 Walter Gropius, The New Architecture and the Bauhaus (Cambridge, Mass.: MIT Press, 1965), 20. In the same vein and in more generic terms, Emilio Gentile urges that 'the aesthetics dimension cannot be analyzed separately from the totalitarian conception of politics, for it was a consequence of that very conception.' Emilio Gentile, The Struggle for Modernity (Westport, Ст: Praeger, 2003), 44.

7 Bruno Latour and Albena Yaneva, 'Give Me a Gun and I Will Make all Buildings Move: An Ant's view of architecture,' in Explorations in Architecture: Teaching, Design, Research, ed. Reto Geiser (Basel: Birkhäuser, 2008), 80-89; Victor Buchli, An Anthropology of Architecture (London: Bloomsbury, 2013); Daniel Miller, 'Artefacts and the Meaning of Things,' in Companion Encyclopaedia of Anthropology, ed. T. Ingold (London: Routledge, 1994), 396-419; George L. Mosse, The Nationalization of the Masses (New York: Howard Fertig, 1975); Caroline Humphrey, 'Ideology in Infrastructure: Architecture and Soviet Imagination,' The Journal of the RAI 11, no. 1 (2005): 39-58; Lawrence J. Vale, Architecture, Power, and National Identity (Yale: Yale University Press, 1992). 
masculinity, discipline, authority, and strength. While it could also fulfil this role, fascist architecture and urban planning under Mussolini and Hitler was assigned the particular task of embodying the utopian future into which fascist nations were soon to be transformed. Its paradigmatic examples are the Palazzo della Civiltà e del Lavoro in Roma and the Ministry of Propaganda in Berlin.

Another conceptual clarification is required: according to the most recent scholarship modernism is more than a drive for innovation and experimentation in the artistic and aesthetic sphere; therefore, apart from representing a rebellion against the anarchy, degeneracy and anomie of modernity and, in strictly architectural terms, an 'attempt to create a form suitable for the new machine age,', it is also a socio-political phenomenon in its own right. Indeed, Fascist Italy and National Socialist Germany fall into this category because, as much as communist Russia, they were revolutionary regimes that did not reject modernity as such, but only its 'degenerative' aspects, and strove in their own way to create an alternative modernity. ${ }^{9}$

The Portuguese history of architecture should overcome the tendency to identify aesthetic modernism, in its strict definition, ${ }^{10}$ with progress and traditionalist aesthetics with political conservatism. ${ }^{11}$ To give but one example, Nuno Teotónio Pereia and José Manuel Fernandes claim that the 'rationalist and functionalist models did not have a future within the ideological framework of the regime.12 As is the case of other regimes, Portuguese modernist buildings, those closer to the functionalist paradigm, could be designed by right-wing architects, and architects with left-wing sympathies could reject

8 Cristopher Crouch, 'Architecture, Design, and Modern Living,' in The Oxford Handbook of Modernisms, ed. Peter Brooker et al. (Oxford: Oxford University Press, 2010), 618.

9 See Griffin, Modernism and Fascism.

10 For a broader definition of modernism, which includes all modern architectural manifestations, see Joana Brites, 'Is There an Ideologically-Biased Broadening of the Concept of Modern Architecture? Questioning the Limits of Postmodernism's Inclusivism,' RIHA Journal 0133, 15 July 2016.

11 This is the case of the following publications: José Manuel Fernandes, 'A Português Suave,' in Arquitectura do Estado Novo (Lisbon: IPPAR, 2003); Ana Tostões, Cultura e Tecnologia na Arquitectura Moderna Portuguesa (Lisbon: IST Press, 2002); Ana Vaz Milheiros, Habitar em Colectivo: Arquitectura Portuguesa antes do S.A.A.L (Lisbon: Departamento de Arquitectura e Urbanismo do ISCTE Instituto Universitário de Lisboa, 2009). It seems more a disciplinary blind spot rather than a national one. See David D. Roberts, Alexander De Grand, Mark Antliff and Thomas Linehan, 'Comments on "The Primacy of Culture”, Journal of Contemporary History 37, no. 2 (2002): 268.

12 Nuno Teotónio Pereira, José Manuel Fernandes, 'A Arquitectura em Portugal' Arquitectura 4, no. 142 (July 1981): 42. 
modernism. To take one example, the architect Manuel da Rocha Casquilho openly criticized the architectural modernism of some buildings commissioned by the state for having been made in 'the [geometrical] box style, ${ }^{13}$ and at the same time he had supported the Movimento de Unidade Democrática ${ }^{14}$ a democratic movement that gathered thousands of the New State's opponents, striving for free elections in 1945. It is also necessary to take into account that the so-called 'first architectural modernism' (late 1920s and early 1930s) in Portugal was pioneered by architects that would become state functionaries, (since the state was almost their only client). ${ }^{15}$ So much so that a prominent Portuguese architect, Cottinelli Telmo, ${ }^{16}$ who had consistently worked for the regime, would make fun of Casquilho with the taunt: 'Poor Casquilho: when the Marquis of Pombal died he lost one of his great collaborators. ${ }^{17}$ Pombal was an eighteenth-century statesman who was responsible for the political decision to re-build the centre of Lisbon after the 1755 earthquake.

This article will focus on those public projects that were built, but also on the utopian projects and other plans that did not come to fruition due to a lack of funding or for some other reason. The analysis concentrates on architecture and urban planning from 1932, the moment Salazar came to power, up to 1943, when Duarte Pacheco, the minister of Public Works, died in a car accident. During this period Pacheco was also de facto Lisbon mayor (1936-1943), and in this role he made huge efforts to reshape Lisbon in a way that befitted the head of the Portuguese colonial empire, proof of the nation's glorious past and guarantee of its present and future greatness, a vision that coincided with the palingenetic visions of contemporary fascist movements (e.g. in Italy, Germany, Britain, and Spain) and corresponded to the years in which Fascist architecture thrived under Mussolini.

From 1928 onwards, Salazar became Minister of Finances of the Military Dictatorship established two years before, and started to control the state apparatus through his ministry. Salazar had gradually centralized the decisionmaking process, which is particularly clear in the case of the Ministry of Public Work, created in $193^{2}$ when he finally became President of the Council.

13 Biblioteca da Ordem dos Arquitectos (воА), National Union of Architects, Minute of the Board Meeting, n. 178, 17 August 1938.

14 Casa Comum, pt. 10390.001, fl. 87, accessed March 8, 2016, http://casacomum.org/cc/ arquivos?set=e_8746.

15 Pedro Vieira de Almeida, O Tronco da Arquitectura - Do Racionalismo como borbulha (Porto: CEAA, 2002), 27.

16 João Paulo, Cottinelli Telmo, ed., Os arquitectos são poetas também (Lisbon: EGEAC, Padrão dos Descobrimentos, 2015).

17 BOA, National Union of Architects, Minute of the Board Meeting n. 178, 17 August 1938. 
The redrawn constitution was approved in 1933, officially inaugurating the New State, but it is very doubtful that this event had had impacted on the public work program. Duarte Pacheco had become minister in 1932 and, from that time onwards a very intensive public works program was put into practice. Among the initiatives, there is the Portuguese Pavilion of in the Paris exhibition of 1937, the monumental fountain of Alameda, the Portuguese Pavilion for the NYC exhibition in 1939, the two maritime stations that received the foreign tourists for the Portuguese World Exhibition in 1940, and so forth. Even the Areeiro neighborhood of Lisbon and university of Coimbra were planned under Pacheco's rule. These works were carried out during the process of the regime's consolidation. The newly created Polícia de Vigilância e Defesa do Estado [political police], censorship, an official propaganda machine (Secretariado Nacional de Propaganda), and corporatist structures all played important roles in shaping the regime's internal cohesion. The same occurred with numerous organizations inspired by the fascist regime that were established by the mid1930s, such as the paramilitary youth movement (Mocidade Portuguesa) and the militia (Legião Portuguesa). All these temporally coincided with the major architectural projects of the time, which justifies the chronological scope of this article.

The aim is to assess if there is at any stage the discernible will on the part of Salazar's regime to promote the kind of political fascist modernism which Roger Griffin has identified in the Nazi and Italian states, one which expresses the project to create a new man and inaugurate a new historical era. Was the regime embracing a new language to express genuine political fascist leanings, was it simply imitating what can be perceived as the fascist style to suggest a kinship with the fascist regimes which was no more than a façade? Alternatively, was it in search of an authentic symbolic language for the 'national resurgence' that, in spite of being an innovative, and in that sense modern, was not fascist?

\section{Salazar's Point-of-View: 'An Architecture within our Time'}

From the moment Salazar seized power in 1932, he became committed to significantly promote new public buildings as achievements that were in stark contrast with the inertia of the previous parliamentary regime. Countless building programs were carried out by Salazarism: airports, hospitals, schools, public housing, stadiums, and courts of justice. He thought those programs were 'a great opportunity to give a certain unity to the official architecture', a chance 'to create something new within the national climate', a new national 
architectural style, capable of epitomize the 'national resurgence'. The preoccupation with newness was in line with what he stated during the 1940 commemorations: 'We are not just because we were, we do not live just because we have lived, we live to carry out our mission and claim to the world the right to do it. ${ }^{18}$ By this he was somehow projecting his plans for the future, an alternative future that although not being fascist, did not exactly aim to turn towards the past.

It is known that Salazar's first concern was the conservation of traditionalist buildings: 'the meticulous, almost religious restoration of what we had, and was about to be lost forever, or is almost lost already continues without a break: after the temples, the restoration of castles, that is, the monuments of military art. Close by, the museums, the national palaces. ${ }^{\prime 19}$ Those were testimonies of the Portuguese past greatness that ought to be preserved for future generations.

But, as regards the new, he expressed his regret that young Portuguese architects, 'among whom there are many talented boys', were not striving to create a new architecture 'appropriate for our time but, at the same time, fitting our race and our climate. The dictator accused architects of 'subserviently following foreign models', taking for 'decorative and modern motifs' what was merely 'a defence against certain climates. ${ }^{20}$ It is clear that none of the works designed by the Portuguese architects until 1932, and that are those considered the more progressive - the so-called Portuguese first modernism - represented the national resurgence as conceived by Salazar. Specifically referring to modernism's long horizontal windows, Salazar has considered that they had been imagined for 'shady countries, where the light is thin and sad' while in Portugal 'the sun infiltrates into every nook and cranny' and 'light needs to be dimmed'. He had even said the excess of light was responsible for eye diseases in Algarve, an area in the south of Portugal where the climate was sunny. ${ }^{21}$

Salazar's sense of newness was rather peculiar. When visiting a recently built council residential complex, which was composed of single-family houses, Salazar rejected the prospect of building a skyscraper in Portugal. According to

18 António Oliveira Salazar, Discursos e Notas Políticas, 1938-1943, volume 3 (Coimbra: Coimbra Editora, 1944) 259 .

19 Entrevistas de António Ferro a Salazar (Lisbon: Parceria A. M. Pereira, 2003), 58-59 [3rd interview, November/December 1932].

$20 \quad$ Ibid., 134-135.

21 Ibid., 134. This judgment would have been influenced by the problems experienced by certain buildings that adopted flat roofs and horizontal volumes which cause problems of overheating and superheating as it was the case of the Beja High School in the south of Portugal. 
him, small independent houses would promote silence, tranquillity and love, the sense of ownership, therefore the sense of family would be enhanced. Conversely, huge blocks would instigate 'promiscuity, revolution and hate', because in there 'individuals become a crowd. ${ }^{22}$ No wonder he had vetoed a proposal to erect a ten-story building with one hundred apartments designed to house intellectuals and artists in Lisbon. On this occasion, he had to mention to the architect responsible for the idea, Jorge Segurado, what happened during the brief Austrian February Uprising in 1934. The Karl Marx Hof, a huge housing complex in Vienna, had been the scenario for a battle between workers and Austro-fascists. ${ }^{23}$

Salazar's defense of an agrarian landscape was not only based on the need to avoid class conflict, but was also rooted in his belief in the corrupting power of modernization: 'Mechanization, the automatism of progress that turns men into machines, isolates them brutally, replacing their tastes and affective impulses by complex and cool gears. The town's man - shaped in his own struggle with others who dispute with him his place in the sun - is, perhaps not noticing it, the incarnation of selfishness. ${ }^{24}$ The alternative future Salazar conceived was that of the transformation of the country into an immense rural area even if the expression 'appropriate to our time' means not a revolutionary palingenetic form of expression, but rather an architecture that did not reject the legacy of the past for the sake of a nebulous future.

His traditionalist nationalism led him to comment, whilst passing the neighborhood of an economic housing complex whose houses contained small vegetable gardens: 'What a beautiful cauliflower! What beautiful roses!' ${ }^{25}$ The concerns he had shown when preparing his move to the official residence of the President of the Council reinforced his conservative, if not reactionary, nature. In an extensive handwritten document that is now held by the National Archives, Salazar meticulously planned how to accommodate chicks, chickens, and rabbits within the palace's premises. He also planned a kitchen to cook for the animals, a compost heap, and a place to channel the dirty water from washing. Further, he established that the 'orderly' and 'peaceful' drivers' home should include a sewing room and maintain a high standard of cleanliness. ${ }^{26}$

\footnotetext{
22 Entrevistas de António Ferro a Salazar, 169-170 [7th interview, September 1938].

23 Interview with Jorge Segurado, Jornal Arquitectos, no. 76, 15 August 1989.

24 Entrevistas de António Ferro a Salazar, 171 [7th interview, September 1938].

25 Ibid., 169.

26 Torre do Tombo Archive (тT), Arquivo Oliveira Salazar (AOs), Correspondência Oficial (Co), Obras Públicas (OP), f. 1, p. 10.
} 
By this means, Salazar had sought to recreate rural life in the urban context. Indeed, he never liked travelling abroad and even less flying, and country was the place where he really felt at home, a feeling that did not change over time. In 1962, Salazar wrote to the director of the Coca-Cola brand in Europe explaining his opposition to its access to the Portuguese market:

it is a matter of what I would call a moral landscape. Portugal is a conservative nation, paternalistic and - may God be praised - a backward country, which I consider more flattering than pejorative. You will risk introducing in Portugal what I hate most of all, i.e., modernism and the famous 'efficiency'. I even shudder at the thought of your trucks at full speed on the streets of our old cities, speeding up, as they pass, the pace of our secular habits. ${ }^{27}$

The route to the future would have to be slow. But, although having a personal taste and opinion about any topic, the truth is that Salazar lacked the skills required to deal with aesthetics and lacked even more the qualities needed to deal with architecture or urbanization. With a humble and rural family environment, and without an artistic background, his expertise was in law and finances. Not surprisingly, his library, which contained thousands of books, is paradigmatic since it held few books on architecture: the Urban Plan of Rio de Janeiro, in Brazil (c. 1930), a book on the new architecture of villages (1913), and the catalogue of the Albert Speer's exhibition 'Modern German Architecture' (1941), the same edition that had been displayed in Belgrade, Budapest and Sofia in 1940, in Barcelona and Madrid in 1942, and in Copenhagen, Istanbul, Ankara and Smyrna in $1943 .{ }^{28}$

Presumably, those books were presents, not acquisitions, and Salazar's lack of preparation to choose an architectural language led him to give carte blanche to his Public Works' minister, knowing that Pacheco would have the ability to successfully 'write in stone' the virtues of the Portuguese genius and the efficacy of Salazar's government. Therefore, the minister Duarte Pacheco had become the key motivating force behind the public works' policy.

27 Cited in Maria Filomena Mónica, Cenas da Vida Portuguesa (Lisbon: Quetzal, 1999), 30-31.

28 Harald Bodenschatz, 'Urban Design for Mussolini, Stalin, Salazar, Hitler and Franco (1922-1945),' Planning Perspectives 29, no. 3 (2014): 381-392. 


\section{Pacheco's Iron Fist}

Duarte Pacheco had been dean of the Lisbon Instituto Superior Técnico [IST; School of Engineering] (1927-1932, 1936-1937), and minister of Education (1928). As such, he had promoted the new faculty facilities. Contrary to what was common practice, and as a mark of confidence in his technical competence, ${ }^{29}$ Salazar would issue him extraordinary powers, while the head of government remained (almost) outside the process. The fact that he avoided public speeches and inaugurations confirmed his reputation as a technocrat, even if his role as a politician had been very well documented by a great deal of written sources. ${ }^{30}$ Yet, Pacheco led the ministry of Public Works with an 'iron fist' and made full use of the authoritarian context by both forcing low interest rate loans to municipalities for public works, and promoting large expropriations. His draconian expropriations policy, ${ }^{31}$ that has parallels in diverse forms of regime, although much easier to apply in dictatorial contexts of the sort provided by Fascist Italy and Salazarist Portugal, enabled him to take possession of significant amounts of private property. In fact, from 1932 until Pacheco's death in 1943, one-third of the Lisbon municipality was expropriated, most of the plots being designated and valued as rural. Following expropriations, the municipality could sell the land together with urbanization projects, thus benefiting from its valorization. ${ }^{32}$

Pacheco also created the Comissariado do Desemprego [Commissariat of Unemployment], an institution under his direct supervision that was financed by an income tax for public work funding. The purpose was to fight against unemployment and provide the country with cheap labor, a kind of Portuguese New Deal program that enabled him to fund his intensive building program.

29 Filipa Raimundo, Nuno E. Ferreira and Rita Almeida de Carvalho, 'Political DecisionMaking in the Portuguese New State (1933-9): The dictator, the Council of Ministers and the Inner-Circle,' in Ruling Elites and Decision-Making in Fascist-Era Dictatorships, ed. António Costa Pinto (New York: Columbia University Press, 2009), 160-161. See also Rita Almeida de Carvalho, A Concordata de Salazar (Lisbon: Temas e Debates, 2013), 218-223.

30 It was Duarte Pacheco who first convinced Salazar to accept the invitation to be minister of Finance in 1928 which eventually would become the first step of Salazar's political career. See João Ameal, ed., Anais da Revolução Nacional, volume 2 (Porto: Emp. Editora Majesta, 1956), 211.

31 Haussmann's Paris, Horthy's Hungary, and contemporary Brazil also provide examples of draconian expropriation policies. This is a theme that deserves a comparative approach which has not yet been applied.

32 See Vítor Matias Ferreira, A Cidade de Lisboa: De Capital do Império a Centro da Metrópole (Lisbon: Publicações Dom Quixote, 1987). 
Another aspect of his policies that must be taken into consideration is the fact that Pacheco forced all towns with more than 2,500 inhabitants to develop urban plans within three years. Being an engineer eager to establish order and proper hygiene conditions, he realized the problem posed by the shortage of urban planners. Thus, many foreign well-known architects and urban planners were invited to work in Portugal during the thirties, such as Marcelo Piacentini, Calza Bini and Giovanni Muzio, Donald-Alfred Ágache and Étienne de Gröer, and Hermann Diestel. All of them would contribute to enriching the regime's language of national resurgence.

In addition, he consolidated a highly centralized state apparatus that had been already established during the Military Dictatorship (1926-1932). ${ }^{33}$ Building commissioners directly answerable to the minister would draw up extensive programs to erect hospitals, schools, universities, courts of justice, barns, hydroelectric power plants, ports, prisons and police facilities. These commissions were autonomous, emanating from public institutions with authority over public buildings, but it was mandatory to ask for the non-binding recommendations of certain state advisory bodies. Usually, each commission brought together an engineer, an architect and someone professionally related with the function of the planned building. Often its members were sent throughout Europe and, more rarely, to the USA, to study the example of other countries.

Travelling abroad to learn from experience elsewhere at the expense of the government was a common practice in Europe. According to Beleza dos Santos, a criminal law expert and the head of the commission in charge of studying new prisons to be built by the regime, in order to appraise other penal systems, German technicians had been recently sent to the USA; Greek, English and Spanish technicians had been sent to Belgium; Belgians had visited the Netherlands and England; and Swiss technicians were sent to the Netherlands and Denmark. ${ }^{34}$ On the periphery of Europe, Portugal would use this way of working in order to properly prepare architects and engineers to make informed, educated choices: Carlos Rebelo de Andrade was sent to Spain to study school buildings (1933); ;5 Pardal Monteiro was sent to Spain, France, Belgium, Holland and Italy to study harbors, ports and maritime stations (1936); ${ }^{36}$ Cottinelli

33 See letter from the Directorate General for National Buildings and Monuments (DGEMN) to the head of office of the Minister of Finance, 10 February 1932. Forte de Sacavém, DGEMN: DSARH/125-4061/01.

34 Letter from José Beleza dos Santos to the Minister of Public Work, s.d., Forte de Sacavém, DGEMN: DSARH-0004/000-0001/01.

35 Forte de Sacavém, DGEMN: DSARH-PESSOAL-002/04.

36 Forte de Sacavém, DGEMN: DSARH-005/125-4686/05. 
Telmo was sent to Holland, Belgium and Germany to study prisons (1935);37 Adelino Nunes was sent to the USA to study post offices (1939); ${ }^{38}$ Guilherme Rebelo de Andrade was sent to Italy to study theatres (1939). ${ }^{39}$

The political clout of Pacheco is reinforced by some other evidence. Due to its high cost, Salazar did not want to build certain major projects of high symbolic importance for the 1940 Exhibition of the Portuguese World, e.g. Fonte Luminosa [Monumental Fountain], the Grande Esfera dos Descobrimentos [Great Sphere of the Discoveries], and the Padrão dos Descobrimentos [Monument to the Discoveries], all of them located in Belém, the Lisbon place historically related with the 'Discoveries' in which the exhibition was depicted. Usually unwilling to compromise, the President of the Council wrote the following dispatch: 'As the minister of Public Works has been responsible for the oversight of the works and discipline of budget, the problem's solution should be entrusted to him'. ${ }^{40}$ And Pacheco would succeed in imposing his vision, for in the event all the three buildings were erected, and one of them, the Monument to the Discoveries, went on to become one of the most representative buildings of the regime.

This modernization impulse does not mean the minister had ever had any sympathy for modernist aesthetics. Cottinelli Telmo gave us a clue about his office decoration: 'all of us have always had great difficulty in getting out of his office, extensively searching - a long search that endangered protocol the drapery edge that would discover the exit door and that was mingled with the folds of outstanding velvets, with no apparent way out.'41 If his personal taste was not enough to sustain the argument, Pacheco library's catalogue reinforces it: the single book vaguely related with architecture and urban planning was a second edition of the Urbanistica - Giardini, published by Filipo Basile, an Italian architect from the nineteenth century. ${ }^{42} \mathrm{He}$ had probably bought this book in 1937 when accompanying the architect Pardal Monteiro ${ }^{43}$ to Italy in order to collect impressions of its maritime stations. Given this disinterest

\footnotetext{
37 Forte de Sacavém, DGEMN: DSARH-PESSOAL-0153/o2

38 Forte de Sacavém, DGEMN: REE-0383/1.

39 Forte de Sacavém, DGEMN: DSARH-010/125-0071/030.

40 See TT, AOs, CO, PC-22, f. 18, TT, AOS, CO, PC-22, f. 25.

41 Forte de Sacavém, José Cottinelli Telmo, JCT-TXT-oo66.

42 The catalogue of Pacheco's library is held by the IST Archive.

43 On Pardal Monteiro's architecture see, among others, João Vieira Caldas, Porfírio Pardal Monteiro - Arquitecto (Lisbon: Associação dos Arquitectos Portugueses, 1997); Ana Tostões, Pardal Monteiro: Fotobiografias Século XX (Lisboa: Círculo de Leitores, 2009); João Pardal Monteiro, Para o Projeto Global: Nove Décadas de Obra - Arte, Design e Técnica na Arquitetura Do Atelier Pardal Monteiro (Lisbon: Faculdade de Arquitectura, Universidade Técnica, 2012).
} 


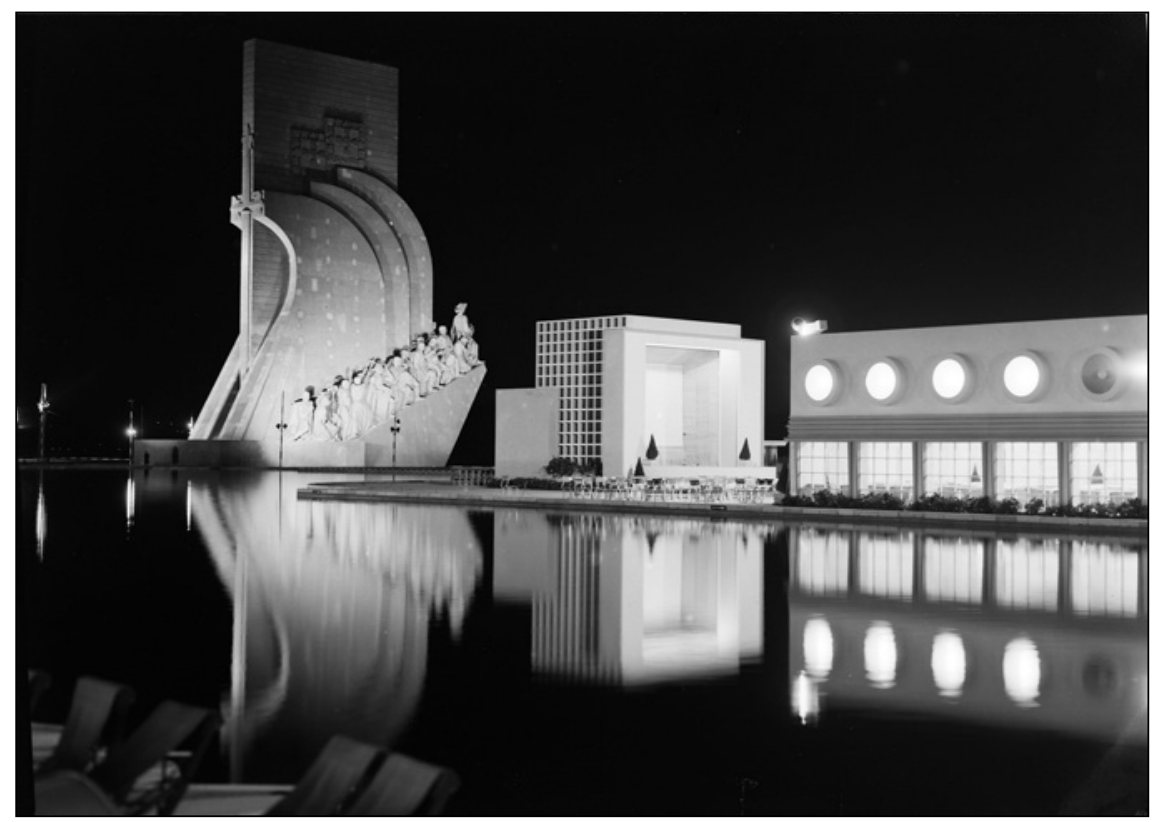

FIGURE 1 Monument to the Discoveries, Lisbon, 1940, by arch. Cottinelli Telmo and sculptor Leopoldo de Almeida. Photographer: Mário Novais.

SOURCE: ART LIBRARY FUNDAÇÃo CALOUSTE GULBENKIAN, CFTO03 025654.IC.

in contemporary aesthetics, the engineer would avoid taking a stand on design matters, opting instead to delegate them to architects and engineers he trusted. Given this, no wonder that, from 1932 up to 1938, Monteiro was Pacheco's righthand man. From 1938 onwards, after a personal misunderstanding between them, the minister replaced Monteiro by Cottinelli Telmo, another important Portuguese architect, even less modern than Monteiro.

But the juncture created by Pacheco's appointment could have been an opportunity to embrace a revolutionary modernism written in stone. Why then was Pacheco's intensive modernizing building policy unable to seize the chance for a radical renewal of Portugal's built environment? Why was a modernized version of traditionalism still the dominant language of the New State during this period?

\section{The Material Shape of the 'Spirit of Discovery'}

In 1932 Salazar came to the conclusion that the Portuguese architects had been so far unable to create an architectural expression of the 'national resurgence' 
as Italy had successfully done. ${ }^{44}$ Considering his abhorrence of the Modern Movement and its geometrical forms, in all likelihood he was not aware of the rationalist architects that were working for Mussolini's regime. Salazar was referring to Piacientini's stripped classicism, considering him and those adopting the same architectural style as the authors of 'monumental fascist architecture', significantly considering it 'highly debatable, but conspicuous.' ${ }^{35}$

Therefore, Salazar had overlooked the fact that no single architectural style was established by the Fascist regime, for contradictory proposals coexisted as long as they help to 'create the monumental Rome of the twentieth century.'46 Salazar, as almost all his contemporary Portuguese elites, ignored that a judicious use of volumes, proportions, scale and ornaments, could translate the myth of Romanità into reality. ${ }^{47}$ Exactly like Salazar, many Portuguese architects were unable to grasp this ambivalence. Indeed, those who adopted both a more international language and a national style praised Fascist architecture, the former for being 'audaciously modern' and the latter for being 'traditionalist'. While one faction could have been attracted by the rationalist style of Giuseppe Pagano and Giuseppe Terragni, others could have become lured by Marcelo Piacentino's severe stripped classical style, which had had many advocates even within democratic nations. If style did not define fascist architecture, what then distinguished its character?

What seems to be the uniqueness of the interwar dictatorships' architecture is the effectiveness with which it conveys the national myths and its projection into an imagined future. This uniqueness was acknowledged by the Portuguese architect Pardal Monteiro. In 1936, Monteiro told to Salazar that what had occurred in politics had happened first in architecture: artistic disorder had been followed by simplicity, embrace of technical advances and purity of the classical spirit. Reacting against the recent past, architecture, like politics, did not wish either to destroy or resurrect the past. In the same way, political institutions or social systems from the past were not recoverable. Realities of modern life prevented it. What could be recovered from the past were eternal elements of the national character. Likewise, in a 'rebirth era', architecture should be novel in order to regenerate the nation. 'The styles of the past are

\footnotetext{
44 Entrevistas de António Ferro a Salazar, 134-135 [6th interview, November/December 1932].

45 Ibid.

46 Richard Etlin, Modernism in Italian Architecture (Cambridge, Mass: The MIT Press, 1992), 392.

47 Diane Ghirardo, Building New Communities: New Deal America and Fascist Italy (Princeton, NJ: Princeton University Press, 1989), 10; Emilio Gentile, Fascismo di pietra (Roma-Bari: Laterza, 2007), 96-7; Griffin, Modernism and Fascism.
} 
beautiful but intangible and sacred. To emulate them is to deny the Portuguese tradition: the spirit of creativity and discovery. 48 What could be resurrected was 'the national spirit and morals', which would make it possible to awaken the Portuguese race's creativeness and 'spirit of discovery'. In Monteiro's view who, as others, always claimed to be apolitical - that spirit was 'the driving force of the race', which meant not going back to the past. According to him, during the nineteenth century Portugal was dragged down by political and social struggles that had plunged the country into deep decay. Now the country had been rescued by Salazar, who had been chosen by God to put Portugal on the right track after the chaos of the First Republic, and architecture had to respond to the vast effort that had been made for 'the race'. By doing so, he was not arguing anything more than what was claimed in the regime's propaganda. But Monteiro also pointed out that Mussolini had defended modern architecture and refused to be defeated by the past. To illustrate this point, he reproduced a speech given by the Italian dictator at the thirteenth International Congress of Architects:

Eternal Rome will be always timeless. ... A few years ago, Rome was a historical city. Fascist Rome, crossed by new and beautiful arteries, is a city of today in which everything that represents the past is cherished, preserved and reconstituted, providing that this does not damage its development in Fascist Era. . . . Fascist Rome couldn't be crushed under so many old stones in a way that it could not breathe. Therefore, alongside the other buildings from other eras there are the Fascist-era buildings, which will indicate to the future what Italy was in that moment. ${ }^{49}$

Pardal Monteiro also explained that there were two opposed Italian Fascist architectural trends - modern versus academic classicism. And Mussolini had chosen to foster modern architecture because the Duce believed that within this context a true Italian architecture would arise. Therefore, he advised Salazar to do the same since the country had already re-discovered its historical destiny, and a return to the past would mean 'a lack of progressive spirit'.

To sum up, Monteiro was one of the Portuguese modern architects of the time and in political terms he proposed a future-orientated modernity. He had designed the Lisbon School of Engineering, and because of that he had become friends with Pacheco, the Minister of Public Works, and his buildings,

48 Letter from Pardal Monteiro to Oliveira Salazar, 8 September 1936. TT, AOs, Correspondência Particular (CP), 184, f. 6: 81-116. 
although still making concessions to Art Deco, would come to epitomize a form of modernism. Others adopted a more daring language, as is the case of the Portuguese architect Carlos Ramos (1897-1969) who designed the Pavilhão do Rádio [Institute of Oncology, 1927] in rational style, which perfectly fits the definition of aesthetic modernism, here meaning Modern Movement, as it was conceptualized by Richard Etlin: 'pure prismatic forms devoid of applied ornamentation and free of stylistic reminiscences, an architecture intended to reflect the spirit of a new machine civilization. ${ }^{50}$ It is necessary to have in mind that those buildings were erected during the Military Dictatorship when Salazar was still a mere university professor in Coimbra, which probably made their construction less problematic.

Many Portuguese architects designed radical, even utopian projects that could perfectly fit within the category of revolutionary fascism, as they clearly represent futural visions of Portuguese society. Such is the case of the funicular planned by Monteiro to cross the Tagus River, and stretching over three kilometers (1939-1940?), and the lift rising 150 meters to a platform set right in the Lisbon center that Jorge Segurado had imagined in 1929 would be the site for an image of the first Portuguese King, a monumental statue that would revolutionize the Lisbon cityscape. In the same vein, a modernist project to be built as a monument to the discoveries in Sagres was designed by Rebelo Andrade in 1934, while in 1930 Cassiano Branco designed a beach resort for Costa da Caparica which was located in the outskirts of Lisbon, that included a luxury hotel with 1,500 rooms, another one with two thousand rooms, a casino, two theatres, one of them an outdoor building with capacity for five thousand people, cinema, covered swimming pool, pedestrian bridges, a channel for the practice of water sports, an extensive sports complex, a dock, and an airstrip.

This project incorporated all of Le Corbusier's ' 5 Points of Modern Architecture' (1926): pilotis, roof garden, free façades, free plan, and horizontal windows. In relative terms, Cassiano's plan brings to our mind the resort Hitler envisaged for Germany, Prora, with its 20,00o beds. Therefore, whether by associating themselves with the Modern Movement or adopting a more or less nationalized variant of a stripped classicism, the 'anthropological revolution' that Roger Griffin claims to be at the heart of fascist political modernism could have had its equivalent in the plans for a new type of Portuguese mass modernity driven by the myth of the Portuguese Discovery and symbolized in daring new architectural projects.

50 Richard Etlin, Modernism in Italian Architecture, XVII. 


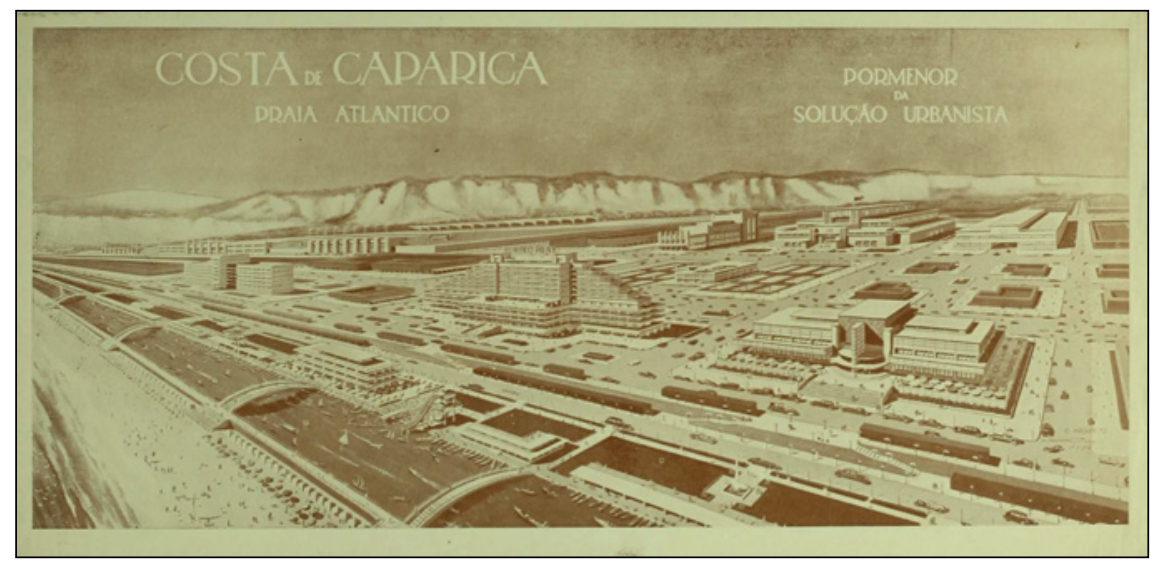

FIGURE 2 Urban plan for Costa da Caparica beach, [1930], by Cassiano Branco. SOURCE: ARCHIVE OF THE LISBON MUNCIPALITY, PT/AMLSB/CB/09/02/01.

As happened in the Fascist cult of Romanità and the Nazi myth of the Aryan race, the Portuguese myth also gave the nation a sense of greatness grounded in the idea that its people were chosen by God to spread His word, and, paradoxically, that the country was also the original source of the European modernity, thanks to its circumnavigation of the Earth..$^{51}$ Although Portuguese nationalism did not translate into a sense of superiority, at least in regards to other European powers, it was the empire that gave Portuguese nationalism its exclusionist nature. ${ }^{52}$ The Portuguese colonies were living symbols of the nation's sacred legacy'.53 Salazarism used it as a source of legitimacy, and because of that the flag of the House of Aviz, the royal dynasty that promoted the maritime expeditions of the fifteen and sixteenth centuries, was considered by the regime to be 'the flag of the eternal Portugal'. ${ }^{4}$ The Salazarist cult of civic virtues led to the resurrection of the Discovery spirit.

51 José Manuel Sobral, Portugal, Portugueses: Uma identidade nacional (Lisbon: FFMs, 2012), 5o; Luís Trindade, O Estranho Caso do Nacionalismo Português (Lisbon: Imprensa de Ciências Sociais, 2008), 152.

$5^{2}$ Sérgio Campos Matos, Consciência Histórica e Nacionalismo (Lisbon: Livros Horizonte, 2008).

53 Ellen W. Sapega, Consensus and Debate in Salazar's Portugal: Visual and Literary Negotiations of the National Text, 1933-1948 (Philadelphia: Pennsylvania State University Press, 2008), 118.

54 João Ameal, 'Á sombra da bandeira de Aviz,' Boletim da Legião Portuguesa 13, no. 15 (August 1938): 3 . 


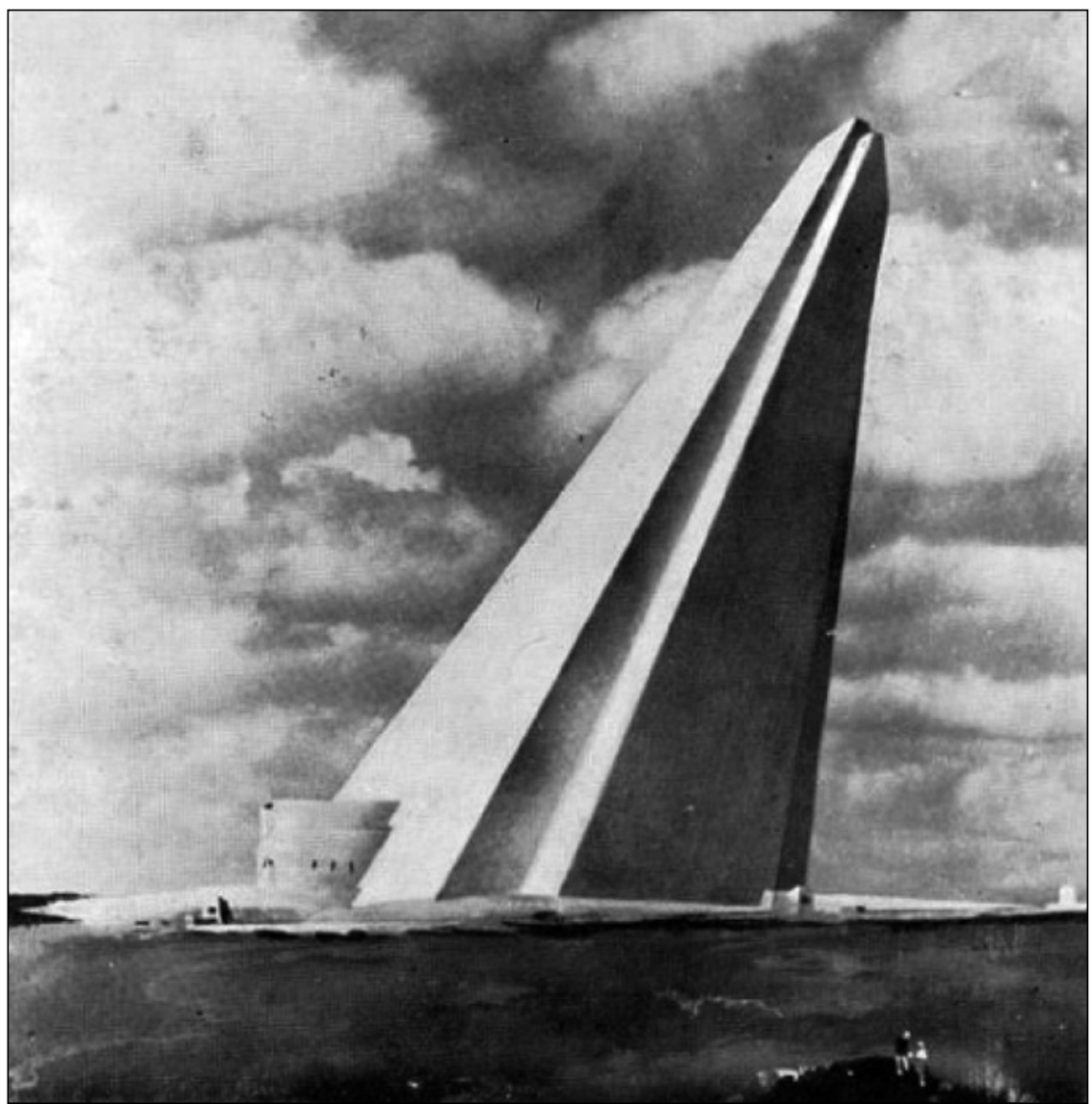

FIGURE 3 'Spreading the Faith and the Empire', competition for a monument to commemorate Henry, the Navigator, in Sagres, South Portugal, 1935, by arch. Rebello de Andrade and sculptor Ruy Gameiro.

SOURCE: ARQUITECTOS, NO. 3, MARCH 1935.

A radical new societal project expressing the unique greatness of the Portuguese people could have been expressed by the Estado Novo architecture, but none of its utopian projects came to be built. A new architecture that would epitomize Portuguese greatness, a kind of future-oriented architectural style, was tested on the three failed attempts to build a monument to pay homage to Henry the Navigator, ${ }^{55}$ the Portuguese prince who had allegedly been

55 Pedro Vieira de Almeida, A Arquitectura no Estado Novo: Uma leitura crítica (Lisbon: Livros Horizonte, 2002). The competitions were held in 1935, 1938 and 1957. 
responsible for turning Portugal into a vast empire, in Sagres, the village that was thought to have hosted the school that taught coastal navigation to those involved in the 'Discoveries'. However, none of the architects' proposals seems to have pleased Salazar and his inner circle.

What confirms that some Portuguese architects had the potential to realize a revolutionary fascist design in architecture is that these professionals were completely au fait with the latest aesthetics movements that were flourishing during the interwar Europe.

\section{Narrow-Minded Architects?}

In 1969 Carlos Ramos stated, referring to the interwar period of architecture, that 'modern theories were not well known by us. ${ }^{56}$ This is largely attributable to the backwardness of the schools of fine arts in Portugal that tried to replicate the Parisian École des Beaux Arts. ${ }^{57}$ However, this claim can hardly be applied to those who worked for the state in charge of designing public buildings. Indeed, the apparently parochial approach to architecture requires a more comprehensive analysis in the context of interwar Europe that can cast light both on the restrained modernism that prevailed, and on the preference for vernacular traditionalism and a nationalized version of stripped classicism, a 'rooted modernism as defined by Roger Griffin within the scope of this special issue'.

It is important to establish how much contact the restricted elite ${ }^{58}$ who worked for the regime actually had with modernism, since it is perfectly clear that many of the architectural undertakings designed by its members were influenced by the architectural currents informing avant-garde projects in Europe. As mentioned before, architects in charge of governmental building programs benefited from study tours paid by the Portuguese government. But

56 Nuno Portas, ‘Carlos Ramos (1897), Walter Gropius (1883) - In memoriam,' Diário de Notícias, 17 July 1969 .

57 See Gonçalo Canto Moniz, O Ensino Moderno da Arquitectura: A Reforma de 57 e as Escolas de Belas Artes em Portugal (1931-69) (PhD diss., Universidade de Coimbra, 2011); Bárbara dos Santos Coutinho, Carlos Ramos (1897-1969): Obra, pensamento e acção: À procura do compromisso entre o Modernismo e a Tradição (MA diss., Faculdade de Ciências Sociais e Humanas da Universidade Nova de Lisboa, 2001).

$5^{8}$ During the Estado Novo a generation of architects that earned a considerable national reputation had followed the Modern Movement: Carlos Ramos, Cottinelli Telmo, Cassiano Branco, Cristino da Silva, Pardal Monteiro, Carlos Rebelo de Andrade, Adelino Nunes, Guilherme Rebelo de Andrade, Keil do Amaral. 
there is much more to add. Indeed, some of these elite members earned foreign degrees. Vasco Regaleira, José Augusto de Magalhães and Augusto José Maria Rodrigues da Silva studied at the Royal Institute of British Architects; Raul Lino received his training in Germany and England; António José de Brito e Cunha, José Marques da Silva, Manuel Marques and David Moreira da Silva obtained the French Degree of Graduate Architect; Fernando de Barros Santa Rita held also a foreign degree. Even more significant was the attendance of Portuguese at international congresses. Adães Bermudes was the Portuguese representative at the 1930 Pan-American Congress in Rio de Janeiro; Carlos Rebelo de Andrade was the Portuguese representative in the Congrès de l'urbanisme colonial in Paris in 1931; Pardal Monteiro was in Prague to attend the Réunion International des Architectes, and in Rome to participate in the 1зème Congrès Internationale des Architectes, both held in 1935; Cottinelli Telmo had also participated in the Prague meeting.

It is also known that they used to attend international fairs. Luiz Cunha, Pardal Monteiro and Cassiano Branco, among others, had the opportunity to appreciate the Le Corbusier and Konstantin Melnikov pavilions exhibited in the International Exposition of Modern Industrial and Decorative Arts, held in Paris in 1925. One of them, Cristino da Silva, would claim the almost all his colleagues subscribed to foreign journals. ${ }^{59}$ They even had personal acquaintances with foreign architects. Pardal Monteiro had regular contacts mainly with leading French architects, either neoclassical or modernist, such as Eugène Beaudouin, Marcel Lods, Pierre Vago, Rouz Spitz and André Bloc. Jorge Segurado once met William Lescaze, whom he invited to be American correspondent for the magazine Arquitectos, published by the Sindicato Nacional dos Architectos [National Union of the Architects]. ${ }^{60}$ They even establish professional relationships with famous foreign architects. Such is the case of Carlos Ramos, who presented a proposal for the new Lisbon stadium together with the architect Jan Wils, ${ }^{61}$ a founding member of the De Stijl movement.

Some of them stayed for long periods outside Portugal as in the case of Cristino da Silva, who studied for years in France and Italy, and Jorge Segurado, who stayed one year in the USA when working on the Portuguese pavilion for the 1939 New York World's Fair. This travel had a great impact on Segurado. American skyscrapers led him to write to his friend Pardal Monteiro to say that the only way of grasping 'the entrepreneurial energy of the Americans' was

59 During a meeting at the Architects Union, Cristino da Silva testified that almost all architects subscribed to foreign journals. BOA, National Union of Architects, Minute of the General Assembly n. 41, 17 February 1938.

6o Pardal Monteiro Studio Archive, Folder 69- National Stadium.

61 Forte de Sacavém, CAONEL-oo13/o1 - Estádio de Lisboa - Propostas. 
actually being there. He challenged his friend to join him: 'Prepare your bags and come. Bring [Duarte] Pacheco with you, because what you see here cannot be seen at all in Europe'. He even wrote a book to record the impression North America caused on him. ${ }^{62}$ Skyscrapers, Hollywood actress, black jazz singers, the sphere and the obelisk of the New York World's Fair are among its illustrations.

These demonstrate that backwardness and narrow-mindedness are not conclusive explanations for the embrace of either neo-classical or regionalist traditionalist architecture in which modernity is embraced, but the exclusion of designs suggesting radical, future-oriented fascist ideals. In fact, architects were perfectly capable of a fierce reaction against the forms of the past. The reason why this did not take place will be explained in the following section.

\section{'The Victory of Tradition and Regionalism'}

The weight of tradition in a country in which pre-industrial forms of agriculture predominated, the industrial revolution had not occurred, ${ }^{63}$ mass society was non-existent and, in general, economic and social activities were highly dependent on the state, ${ }^{64}$ was not conducive to the emergence of radical newness, either aesthetic or political, but rather promoted self-restraint on the part of most architects. ${ }^{65}$ 'I have but one purpose: it is to make Portugal continue to follow its normal rhythms of life', Salazar would claim in $1938 .{ }^{66}$ Indeed, the ideology and political discourse promoted by the New State were impregnated with traditionalist values and Catholic moral. ${ }^{67}$ Aided by political repression, propaganda, and the Catholic Church, the regime would partially succeed in

62 Jorge Segurado, Sinfonia do Degrau, Impressões de New-York e de outras terras dos Estados Unidos da América do Norte (Lisbon: Soc. Nac. de Tipografia, 1940).

63 The share of Portuguese working-age population on the primary sector is as follows: 1940 - 49,3 \%; 1950 - 48,4\%; 1960 - 42,8\%. See Mário Cardoso dos Santos, 'Estrutura e evolução da população activa em Portugal,' Análise Social 3, no. 12: 441-474.

64 See Pedro Lains, 'The Portuguese Economy in the Twentieth Century: Growth and Structural Change,' in Contemporary Portugal: Politics, Society and Culture, ed. António Costa Pinto (New York: Columbia University Press, 2011), 131-152.

65 On this topic, see Joana Brites, O capital da arquitectura: Estado Novo, arquitectos e Caixa Geral de Depósitos (1929-1970) (Lisbon: Prosafeita, 2014), 102.

66 'Pour moi, ... je n'ai qu'un but. ... Ce que je me propose, c'est faire vivre le Portugal habituellement.' See Henry Massis, Les idées restent (Lyon: H. Lardanchet, 1941), 20-21.

67 Rita Almeida de Carvalho and António Costa Pinto, "The "Everyman" of the Portuguese New State during the Fascist Era,' in The 'New Man' in Radical Right Ideology 1919-45, ed. Jorge Dagnino, Matthew Feldman and Paul Stocker (London: Bloomsbury, 2018), 131-148. 
imposing this conservative worldview valuing continuity with the past, and, unsurprisingly, material forms mirror it. Not because there was a strict official model imposed by the regime, but because the state apparatus was dominated by technicians and bureaucrats that shared with Salazar his nationalistic principle. ${ }^{68}$ Even distinguished architects and urban planners with international, modern outlooks were obliged to work within this context and, as they needed public contracts to professionally survive, the state being almost their only client - they would adapt to the situation by repressing any modernist or radical impulses they may have had.

In line with Oliveira Salazar, Raul Lino - a key protagonist of the 'Portuguese house ${ }^{\prime 69}$ movement that has to be understood within the context of the nationalism that had arisen in Portugal at the end of the nineteenth century ${ }^{70}$ - was the leader of the nationalist faction among his professional colleagues. Further, he was the one architect who maintained a personal relationship with Salazar, being received by him on a regular basis, and also exchanging private correspondence with the dictator. ${ }^{71}$ Lino considered that a 'new spirit clothing a centuries-old soul was necessary' and that nationalism was 'an urgent need' for the 'reconstruction of the nation'. He called for an 'official dam' against the 'mechanical and uniform style that disparaged the national spirit'.72 Lino had unequivocally condemned geometric forms and rationalism in architecture, ${ }^{73}$ which he blamed for diminishing 'the national sentiment'. In his opinion, while a machine could change its ownership without losing characteristics and efficiency, a building was 'rooted in the soil and had to express its owner's feelings'. Lino also thought that 'the machine style' either 'had its origins in strange and distant countries or served as communist propaganda. ${ }^{74}$

68 Luís Trindade shows the overwhelming impact that literary nationalism had in the Portuguese regime, namely on the rejection of 'modernity as capitalism' and in the praise of the country's 'rural authenticity and incorruptibility', themes that would turn Portugal into the spiritual leader of the fight against contemporary European 'decadence and destruction'. Luís Trindade, 'The System of Nationalism: Salazarism as Political Culture,' in The making of modern Portugal, ed. Luís Trindade (Newcastle upon Tyne, uk: Cambridge Scholars Publishing, 2013), 249-269.

69 See, among others, Rute Figueiredo, A Arquitectura e o Discurso Crítico em Portugal (18931918) (Lisbon: Colibri/IHA, 2007).

70 Trindade, 'The System of Nationalism,' 250-251; José-Augusto França, 'Raul Lino relido,' Diário de Lisboa, Suplemento Literário, 26 November 1970, 8.

71 TT, AOS, DI, 1 and 2.

72 Letter from Raul Lino to Oliveira Salazar, 23 August 1933. TT, AOS, CP-156, f. 21, 140-141.

73 See Raul Lino, 'Afinidades e Analogias,' Diário de Notícias, 12 January 1953.

74 Letter from Raul Lino to Oliveira Salazar, 23 August 1933. 
The fact he had always claimed to have nothing to do with politics did not stop him claiming that architectural rationalism symbolized, if not 'the triumph of Communism', at least 'a great weakness of intellect and regrettable absence of national consciousness.' ${ }^{75}$ For that reason, he considered the 'exemplary model' of architecture in Italy, 'a true mirror of the social remodelling of the country: a new spirit to cover a millennial soul'. He also regretted that Portugal still had not find 'the architectural expression of the great work of the resurgence of the Nation'. He then urged for a Latin architectural language as a way to defeat 'the insidious propaganda of dissolving internationalism ..., which denies all that is traditional. ${ }^{76}$ In Lino's view, architectural nationalism was not a matter of taste, but rather a necessity to reconstruct the nation. 'Respect for traditions', 'rejection of pernicious foreignness', 're-Portugalization' of architecture were his mottos. ${ }^{77}$

Lino's disdain for geometric forms was shared by many other Portuguese intellectuals. António Ferro, the chief of Propaganda - whom many wrongly consider a modernist intellectual ${ }^{78}$ - commissioned a house to build in Sintra adopting the regional style: Portuguese roof tiles and decorated eaves, arched windows, ornaments on the facade, tiles with regional themes and so forth. ${ }^{79}$

Lino and other traditionalist architects sought to use the symbolic power of architecture to help solve the crisis of modernity expressed in the increasingly amorphous, spiritless, faceless aspect of the Western metropolis by recovering the 'eternal spirit' of the Portuguese people. In principle, the projects that resulted could thus have been far closer in fusion of the traditional with classicism or modernism to those analyzed by Roger Griffin and Aristotle Kallis in relation to Fascist and Nazi regimes..$^{80}$ But the alternative modernity they

\section{Ibid.}

76 Ibid.

77 See Raul Lino, Casas portuguesas: alguns apontamentos sobre a arquitectura das casas simples (Lisbon: Valentim de Carvalho, 1933) and Auriverde Jornada: Recordações de uma viagem ao Brasil (Lisbon: Valentim de Carvalho, 1937).

$7^{8}$ On this topic see the groundbreaking studies José Pedro Zúquete, 'In Search of a New Society: An Intellectual between Modernism and Salazar,' Portuguese Journal of Social Sciences 4, no.1 (2005): 39-59; and José Barreto, 'António Ferro: Modernism and Politics,' in Portuguese Modernisms: Multiple Perspectives on Literature and the Visual Arts, ed. Steffen Dix and Jerónimo Pizarro (London: Legenda, 2011), 135-154.

79 Academia Nacional de Belas Artes, Arquivo Atelier Jorge Segurado, n. 22, f. 146.

8o See the articles of Roger Griffin and Aristotle Kallis in the first part of this special issue: Roger Griffin, 'Building the Visible Immortality of the Nation: The Centrality of "Rooted Modernism" to the Third Reich's Architectural New Order,' Fascism: Journal of Comparative Fascist Studies 7 (2018): 9-44, accessed July 20, 2018, doi: 10.1163/22116257-00701002; Aristotle Kallis, 'Futures Made Present: Architecture, Monument, and the Battle for the 


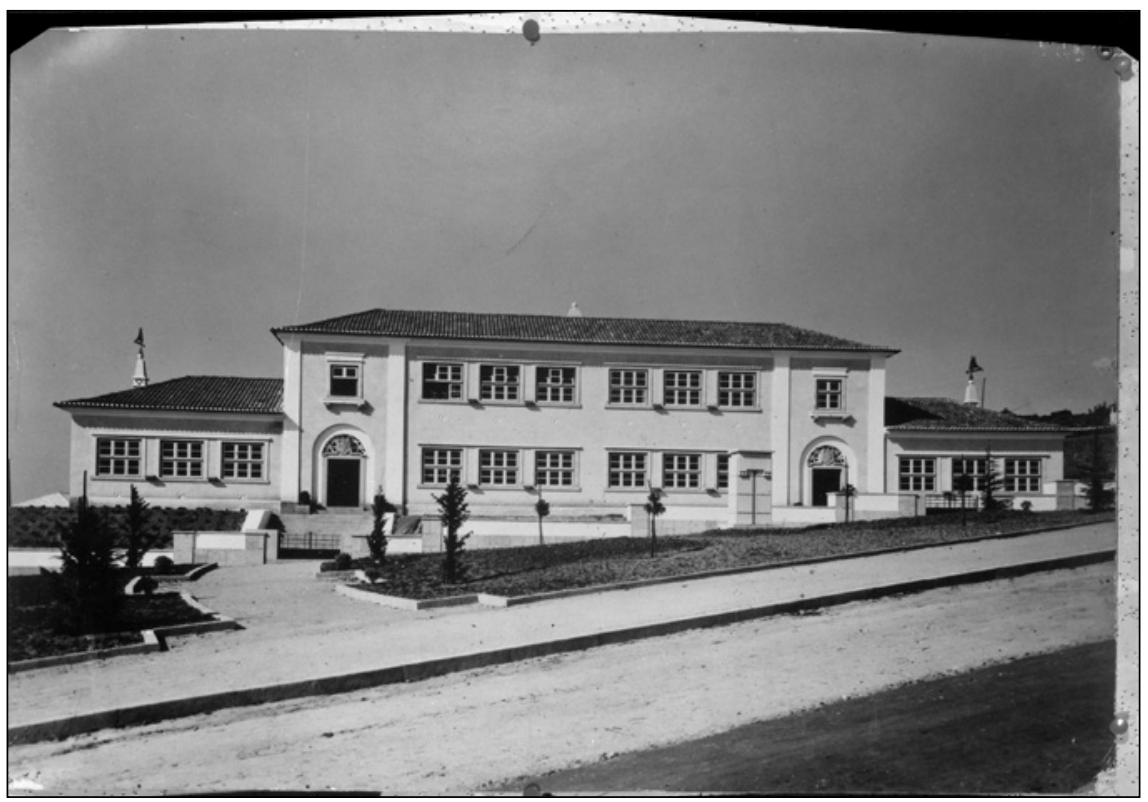

FIGURE 4 Primary School in Ericeira, by Raul Lino. Photographer: Estúdio Mário Novais. SOURCE: ART LIBRARY FUNDAÇÃo CALOUSTE GULBENKIAN, CFT003.23705.

propose was not revolutionary in spirit, and envisaged no radical transformation either in the landscape or townscape, or in the national character of the Portuguese. The lack of a utopian dimension to Lino's creative imagination is evident by the work he was producing long before Salazar seized power.

It is consistent with this that Lino's architecture was not perceived by government agencies as representing the political change politicians were undertaking in the Estado Novo, and so they did not commission any state building from him. For the most part, Lino only designed private houses in an idiosyncratic traditionalist style, sometimes evoking fairy tale scenarios, a kind of 'poem in stone' in which man and nature were in perfect harmony, even if he did not abandon modern functional principles in terms of plan and always reflecting ecological concerns. ${ }^{81}$ But his work played a crucial role in avoiding any hint of modernism's architectural excesses that would conflict with

“Third Way" in Fascist Italy,' Fascism: Journal of Comparative Fascist Studies 7 (2018): 4579, accessed July 20, 2018, doi: 10.1163/22116257-00701004.

81 On the modernity of Raul Lino see Pedro Vieira de Almeida, 'Raul Lino: Arquitecto moderno,' in Raul Lino: Exposição Retrospectiva da sua Obra (Lisbon: Fundação Calouste Gulbenkian, 1970), 115-188; Pedro Vieira de Almeida, Dois Parâmetros de Arquitectura Postos em Surdina: O propósito de uma investigação (Porto: Centro de Estudos Arnaldo 
the conservative nature of the regime and its elites. Their vision of the new Portugal was not reactionary since they were prepared to promote modernization as long as it did not accelerate the pace of change to the point where it disrupted the habits and routines of everyday. Salazar and his supporters saw the solution to the nation's problems in a modernizing conservatism incorporating enough elements of the two fascist regimes to create a strong state protected from liberal chaos and the communist threat, while generating a largely illusory sense of dynamism and modernity. The rebirth they aspired to was a muted, gradual one far removed from the violence of the Nazis' 'creative destruction'. The Portuguese were to live at their own tempo, not one accelerated by radical state policies of regeneration or disrupted by what Walter Benjamin called 'the storm of progress'.

Within the paradoxical ethos of decision-making scheme, Lino was the guardian of the Portuguese soul, which had been recently redeemed by Salazar from the chaos of the modern world. In this effort by the state to eliminate any radical architectural initiatives, he was assisted by other key figures within the state building processes.

\section{The 'Little Dictators' of the State Apparatus}

Raul Lino was supported in achieving his purpose to build modern structures reflecting traditional values by a host of bureaucrats working in the state intermediary bodies involved in the building policy. ${ }^{82}$ Lino was himself a bureaucrat who had a decisive role in the decision-making process as architect-in-chief of the office in charge of studies and works for monuments the Repartição de Estudos de Edifícios - under the Direcção-Geral de Edifícios e Monumentos Nacionais [DGEMN; Directorate-General of Buildings and National Monuments]. His judgments, though not binding, had been decisive in the shaping the material legacy of the New State. For instance, he usually recommended that all windows and doors ought to be surrounded by stone, incidentally bringing them in line with the aesthetic of stripped classical civic buildings of the period. ${ }^{83}$ Lino also wrote a report on the new mint project in

Araújo, 2010). See also Irene Ribeiro, Raul Lino: Pensador Nacionalista da Arquitectura (Porto: Faculdade de Arquitectura, 1994).

$82 \quad$ For a detailed analysis of the state structures involved in public works see Brites, $O$ capital da arquitectura, 87-165. I borrow the expression 'little dictators of the public service' from Pedro Vieira de Almeida, Viana de Lima, 1913-1991 (Lisbon: Fundação Calouste Gulbenkian), 51-96.

83 See, for instance, Forte de Sacavém, DGEMN: DSMN-0288/01 and DSMN-0288/02. 
Lisbon expressing his surprise at the lack of ornamentation, and to counteract its austere effect he proposed that a high relief sculpture should be added to the west façade.$^{84}$ On another occasion, he criticized the project of the Telegraph and Telephone Station, designed by the architect Adelino Nunes to be built in Square D. Luís in Lisbon, which he claimed would not be out of place in any outer borough in New York or in some other city located in the UK or Netherlands: in other words, the project failed to take into account the local conditions and national context. He also had harsh words for the building's industrial, functional style and lack of gravitas. ${ }^{85}$

Apart from DGEMN there were other public institutions involved in the New State's building policy. An important one was the Conselho Superior de Obras Públicas [csop; National Council for Public Works], an advisory body dominated by engineers. In his evaluation of the same mint project, the engineer Ferreira, the rapporteur of the CsOP, described its external appearance as one of 'modern, simple lines and simple décor', 'an uncharacteristic style that only architects with higher artistic skills can apply without relapsing into the grotesque', qualities that in this case the architect did not seem to possess. As the mint would be 'one of the distinctive monuments of the modern cityscape', he argued that the project must be also submitted to the Conselho Nacional de Belas Artes [CNBA; Superior Council of Fine Arts] or to the Aesthetic Committee of the Lisbon Municipality. ${ }^{86}$

For his part, Cordeiro Ramos, the president of the Junta Nacional da Educação [JNE; National Board for Education], ${ }^{87}$ who was also a Nazi sympathizer, privately wrote to Salazar arguing against the mint project. ${ }^{88}$ Ramos' negative reaction was shared by José de Figueiredo, member of the National Board for Fine Arts. Figueiredo, a reputable art historian who was also the director of the National Museum of Ancient Art, would argue: 'justifying his design, the architect says that he only planned three windows on the west façade because no more light was necessary. However, it is a pity that, when drawing the site plan, the architect didn't study its projection on the façade. Had he done so, that distorted result would have been avoided'89 Figueiredo's main concern

84 Report, Lisbon, 15 December 1938, Forte de Sacavém, DGEMN: DSMN-0288/01.

85 Report, Lisbon, 8 November 1941, Forte de Sacavém, DGEMN: DSMN-0288/o1.

86 Forte de Sacavém, DGEMN: DSARH/125-4061/o1, [1934], 99-115.

87 Created in 1929 during the Military Dictatorship, JNE aimed at fostering Portuguese research and its diffusion, promoting cultural interchange, and disseminating Portuguese culture.

88 Letter to Oliveira Salazar, 2 February 1937, TT, AOs, CO, OP, 1A, f. 27.

89 Forte de Sacavém, DGEMN: DSARH/125-4061/o1, 3 September 1937. 
was with aesthetics and it seems his objections were listened to, for the three initial windows of the west façade would become twenty.

There is evidence that the Municipality of Lisbon also interfered in the decision-making process. In response to Pardal Monteiro's designs for the Bank of Portugal's headquarters, a stripped classical building that could, at a stretch, be compared to the work of Speer, some technicians from the Municipality wrote to the governor of the Bank criticizing it, arguing that 'the building had to be built in an architectural language that all good Portuguese people could understand. ${ }^{90}$ The project was never built, suggesting again that the prevailing ethos, zealously guarded by state bureaucracy, militated against radical originality or the adoption of any aesthetic that could be seen as alien, provocative or jarringly modern.

This intricate planning and design process partly explains why the currency of fascist modernism and the plurality of aesthetic styles adopted in Italy ${ }^{91}$ and Spain ${ }^{92}$ was precluded in Portugal during the thirties. The quasi-uniformity of public architecture would be further reinforced by the small size of the country and the state's overwhelming presence in all societal, economic and cultural realms. 'Fascist visions' ${ }^{\prime 3}$ were never the aim of Salazarism and its supporters. Traditionalism, regionalism and nationalized neo-classicism was what suited them the most. However, the prevalence of these aesthetics is not to be mistaken for an established official style, but rather as the result of a successful campaign in favor of nationalism and against radical currents of internationalism which had been fought since the last decade of the nineteenth century, leading to a standardization of taste perfectly in harmony with Salazarist doctrine. ${ }^{94}$ If this had not been the case, architects who are conventionally referred to as 'the first modernists' for adopting of rational style during the early 1930 s would have not freely constructed for themselves private houses in conformity with the regime's allegedly 'official style. ${ }^{95}$ This is the

9o Letter from the Municipality of Lisbon to the Governor of the Bank of Portugal, 27 March 1937. Atelier Pardal Monteiro (APM), 'Caixa B - Assuntos M. Pai'.

91 Etlin, Modernism in Italian Architecture.

92 Carlos Sambricio, 'On Urbanism in the Early Years of Francoism,' in Urbanism and Dictatorship: A European Perspective, ed. Harald Bodenschatz, Piero Sassi and Max Welch Guerra (Berlin-Basel: Bauverlag Gütersloh-Birkhäuser, 2015), 117-134.

93 Matthew Affron and Mark Antliff, ed., Fascist Visions: Art and Ideology in France and Italy (Princeton: Princeton University Press, 1997).

94 Trindade, $O$ Estranho Caso.

95 For the allegedly 'official' fascist architecture of Estado Novo, see, among many others, Nuno Teotónio Pereira, 'Foi o Salazarismo um Fascismo? O que diz a Arquitectura' [Was Salazarism a Fascism? What does architecture say], published in the daily newspaper Público, 18 July 1993. Simultaneously, the same author claims that the Portuguese regime's 
case Cristino da Silva in 1944 and Cassiano Branco in 1945, as Pedro Vieira de Almeida rightly pointed out decades ago. ${ }^{96}$

There may also be more prosaic reasons for the absence of variety and daring within Portuguese architecture. The lack of architectural competitions for prestige projects also probably worked against the development of modernism. Architects always campaigned for more competitions, ${ }^{97}$ but the system of directly awarding public contracts without any administrative procedure had prevailed. ${ }^{98}$ Architect Pardal Monteiro once explained the process by which he was commissioned by the IST dean, Duarte Pacheco, who would soon become minister of Public Works, to design its new campus: 'you are the architect that the school board and I have chosen. Therefore, I only have two options open: to assign you the project for the Institute or to entrust it to a foreign architect, so you choose. ${ }^{99}$ The same architect was commissioned by verbal agreement to design two maritime stations in Lisbon, Alcântara and Rocha do Conde de Óbidos, and no written contract had ever existed. ${ }^{100}$ Even when competitions did take place, programmes clearly laid down the aesthetic orientation to be followed, a practice that was against the recommendations made by the Congrès Internationaux d'Architecture Moderne [CIAM; International Congress on Modern Architecture] in 1928. Such is the case of the competition for the new Palace of Justice in Lisbon in the early thirties. In regard to the 'character of the building', the program stipulates the following:

The competing architects, when designing the building, must bear in mind: (a) the prestige and majesty of the institution for which the building is designed and the high function it serves; ... (c) the monumental

nature is fascist because it is 'totalitarian, repressive and narrowly nationalist and retrograde'. As explained in this article which follows Roger Griffin's theoretical model, those are not the defining traits of fascist regimes. See also, among many others, Nuno Teotónio Pereira, José Manuel Fernandes, A Arquitectura em Portugal, Arquitectura, 4 (July 1981), 38-48; Brites, O capital da arquitectura; Joana Brites, 'Estado Novo, arquitetura e "renascimento nacional", Risco: Revista de Pesquisa em Arquitetura e Urbanismo 15, no. 1 (2017): 100-111.

96 Pedro Vieira de Almeida, 'Arquitectura e Poder: Representação nacional', in Arquitectura do Século XX, ed. Annette Becker, Ana Tostões and Wilfried Wang (München: Prestel, 1998), 96.

97 See вОА, National Union of Architects, Minute of the Board Meeting n. 283, 20 April 1943.

98 See also Brites, $O$ capital da arquitectura, 104.

99 See Ana Tostões, Pardal Monteiro: Fotobiografias Século XX. (Lisbon: Círculo de Leitores, 2009), 55 .

100 'Aquisição de projectos dos edifícios anexos às gares marítimas de Alcântara e Rocha do Conde de Óbidos,' [September 1943], Forte de Sacavém, DGEMN: DSARH-005/125-4498/01. 
character a public building of this nature and the importance it should have; ...; (e) the national character of a building designed and executed by Portuguese architects, engineers, artists, and local conditions should also be conveyed; (g) the advisability of employing, preferably, and as widely as possible, Portuguese materials and labor. ${ }^{101}$

Unlike Fascist Italy, where Mussolini had promoted competitions, and commissions were awarded regardless the style, Portuguese architects were not encouraged to stretch their imaginations due to several factors, such as the elites' parochialism and generally conservative taste, the centralization of the decisionmaking process and the small size of the country. Worse still, many buildings were designed and erected by contractors and engineers rather than architects. In 1937, 715 projects were approved in Lisbon although only sixty-six were designed by architects. ${ }^{102}$ Architects were not professionally recognized, ${ }^{103}$ and contractors were more preoccupied with earnings than with functional architecture.

Hampering the modernization of Portuguese architecture (and its openness to modernism) was also the fact that Portugal did not have a steel industry, a significant factor given that steel and reinforced concrete were the basis of modern functional architecture. ${ }^{104}$ Such activity would be only developed many years after the Second World War: industrial scale extraction began in 1951 and it only acquired a significant dimension from 1961 onwards. Given these conditions, no wonder Salazar's diaries of the thirties show how he and his ministers had spent considerable time discussing how to resolve the issue, which turned out to be even worse as the war drew closer. ${ }^{105}$ In order to fulfil the country's needs, the government had exchanged tungsten for steel with Nazi Germany and also imported it from the USA. Even so, the import of steel was not enough to supply building industry and technicians did what was needed to avoid its use. Such is the case of an unidentified engineer who suggested that the Estoril's post office should have its flat roof replaced by roof tiles due to the excessive price of reinforced concrete. ${ }^{106}$ The contemporary

101 Forte de Sacavém, DGEMN: DSARH-005/125-4425/13 - Programa do concurso para a construção do Palácio da Justiça de Lisboa, [1934?].

102 BOA, National Union of Architects, Minute of the Board Meeting n. 119, 20 October 1937.

103 Until 2009 Portuguese law allowed that architectural projects could be designed by professionals without specific training in architecture.

104 See Jean-Louis Cohen, 'Modern Architecture and the Saga of Concrete,' in Liquid Stone: New Architecture in Concrete, ed. Jean-Louis Cohen and G. Martin Moeller Jr (New York: Princeton Architectural Press, 2006), 20-33.

105 See 'Diários de Salazar' (DI), TT, AOS, DI, 1 and 2.

106 'Estação dos CTt do Estoril', Report, 13 September 1939. Forte de Sacavém, Dgemn: $\operatorname{REE} / 015 / 5^{2}$. 
architect Siza Vieira who won the Pritzker Price in 1992, confirms the impact of this issue when he states: 'In the 1940s, many Portuguese architects dreamt of building in concrete, persistently more expensive than stone, and of using horizontal windows and terraces, that sometimes let in water. Long battles were fought; walls were erected to conceal the hated roof covered with Marseille tiles that no longer meant progress.' ${ }^{107}$ Thus, the lack of steel might have been a significant problem for the modernization of Portuguese architecture.

But it is more likely that the general traditionalist pressure of the elites had been responsible for effectively censuring any radical language that architects might have aspired to use. Adding to this conformist pressure was the threat of direct interference by the dictator, although his role should not be exaggerated. Even if Salazar 'was not prepared to discuss or supply architectonical recipes', and 'he never modified the final result of an architectural project', he was rarely the final arbiter of architectural matters. A recent study that describes the process by which the National Bank projects were approved, shows that, out of a total of eighty-two buildings, twenty-nine renovations, and thirty-three uncompleted projects, ${ }^{108}$ Salazar intervened only on one occasion. In the case of a new project for Coimbra, he asked for information in order to be sure that the recommendation of the Public Work Council, which had advised the replacement of a flat roof by Portuguese roof tiles in the house of the bank manager, was followed. ${ }^{109}$ Coimbra was the University City in which Salazar had studied, taught and developed his Catholic and political militancy, and also the principal school in which the regime's elites were trained. The subject had been brought to a session of the Council of Ministers presided over by Salazar himself, maybe in the context of the new building plans for the university, a topic that had always captured the dictator's attention. ${ }^{110}$

In the end, given their high dependence on the state, architects were compelled to abandon their ideals and did what the regime's leader and its inner circles expected: to accept the recommendations of the state intermediary bodies without a fuss. Therefore, their designs were conceived to suit the project's commissioners who, although unconstrained by state directives, discouraged modernist innovation and experimentation.

107 Álvaro Siza Vieira, 'Post-Modernismo e Arquitectura,' Revista Crítica de Ciências Sociais 24 (1988): 176 .

108 Brites, O Capital da Arquitectura, 295-297.

109 Ibid., 98-100.

110 Nuno Rosmaninho, O poder da arte: O Estado Novo e a cidade universitária de Coimbra (Coimbra: Imprensa da Universidade, 2006). 


\section{Post-Second World War Portuguese Fascism?}

It is only possible to speak of an Estado Novo architecture with regard to some projects that were built from the end of the 1930s onwards, most of which were completed after Pacheco's death and the defeat of the Axis powers, and thus at a time when the 'era of fascism' was over and the regime was struggling to justify its existence that had suddenly became an anachronism. As a result, some buildings of the University of Coimbra and the Areeiro neighborhood, in Lisbon, both planned before the forties and erected after the Second World War, are the most striking examples of a hypothetical Portuguese fascist architecture (see figure 5). This is evident in some common formal elements which are easily recognized: the vast scale of the buildings, the domination of public over private space, neo-classical elements, colonnades, arches, and symmetry.

However, this kind of stripped classical monumental building is part of an aesthetic current of the period that can also be found within democratic regimes. Indeed, there is a significant number of buildings that perfectly fit within this category, such as the main building of Zurich University (1914), Tokyo Palace in Paris (1937), Senate House in London (1932-1937). Some of them, for example the Musée de l'Art Moderne, even have more similarity with Marcello Piacentini's Rettorato in the University of Rome than with Coimbra University, which has some parallels with the Medical School of Paris (1936-1953). In other words, one must be cautious when identifying affinities between the Universities of Coimbra and Rome, a caution which Portuguese historiography, with rare exceptions, ${ }^{111}$ has not followed. ${ }^{112}$

When observing the Coimbra University, in my view, there is not a 'modernist élan towards the future' equivalent to that referred by Roger Griffin when speaking about Piacentini's plans for the EUR $42 .{ }^{113}$ In terms of synesthetic experience, the feeling one gets while walking the spaces of the University of Coimbra is that of the superiority of those who are the custodians of knowledge, one of whom was none other than the former academic Oliveira Salazar. The sense of order, hierarchy, and discipline which the buildings embody convey the importance of the University of Coimbra as the entity which trained the regime's elites, and this contrasts with the emotional appeal of the fascist

\footnotetext{
111 Vieira de Almeida, 'Arquitectura e Poder,' 93-97.

112 See Margarida Acciaiuoli, Os Anos 40 em Portugal (PhD diss., Universidade Nova de Lisboa, 1992); Nuno Rosmaninho, O Princípio de uma «revolução urbanística» no Estado Novo (Coimbra: Minerva, 1996); Brites, O Capital da Arquitectura.
}

113 Griffin, Modernism and Fascism, 235-236. 
buildings. ${ }^{114}$ Such austere emotions are nevertheless somehow softened by the extended use of roof tiles instead of flat roofs, an effect that was even acknowledge at the time. In an excerpt of a report prepared by the Coimbra's agency of the Public Bank, we read: 'Although the author of the project had insisted on retaining the plan for a reinforced concrete roof throughout the construction with the aim of assuring that the impact of the whole building would be enhanced as much as possible, an impact which could in some way be affected by the red patch of roof tiles over a main porch of distinctly classical appearance, the final design was changed in order to replace the flat roof of the indented body by roof tiles.'115 Sculptures, ornamentation, and references to the Portuguese 'spirit of creativity and discovery' also contrast to the architecture of the German and Italian regimes. In the entrance to La Sapienza in Rome, Minerva, a mythological deity, wields a sword and a shield, in a strong, belligerent pose (Arturo Martini, 1935), while in Coimbra the entrance of the university is adorned by three big sculpture of classical authors (Safo, Tucídides, Aristóteles e Demóstenes), as guardians of Letters who contemplate the future with serenity, in the confidence that no revolutions are about to happen.

Coimbra's buildings did not reflect the Fascist slogan 'credere, obbedire, combattere' [believe, obey, fight] as Piacentini's clearly did. ${ }^{116}$ But these fascistized buildings and plans also did not convey the Salazarist motto 'Deus, Pátria e Família' [God, Fatherland and Family]. The President of the Council dreamt of a country transformed into a vast white village in a rural setting, selectively picking up modern commodities such as roads, schools, and telephone lines. His beloved rural utopia as a response to the harmful effects of modernization ${ }^{117}$ was unrealizable, for modernization and urbanization were unavoidable and he knew that were both necessary to the regime future survival. The tension between the leader's ideology and the regime's material legacy is well epitomized in the regime's failure to erect a monument commemorating Henry the Navigator. Unlike Mussolini and Hitler, who were directly involved in architecture and urban planning, Salazar's architectural ineptness led him to rely on architects, and these could not find an architectural language that

\footnotetext{
114 Luís Reis Torgal, A Universidade e o Estado Novo (Coimbra: Minerva, 1999).

115 Letter from Espregueira Mendes, member of the commission for the building of the Caixa Geral de Depósitos' agencies, to the general-director of the DGEMN, 23January 1950. Cited in Joana Brites, O Capital da Arquitectura, 100.

116 Etlin, Modernism in Italian Architecture, XXII.

117 Vera Marques Alves, Arte Popular e Nação no Estado Novo: A Política Folclorista do Secretariado de Propaganda Nacional (Lisbon: Imprensa de Ciências Sociais, 2013), 108-109.
} 


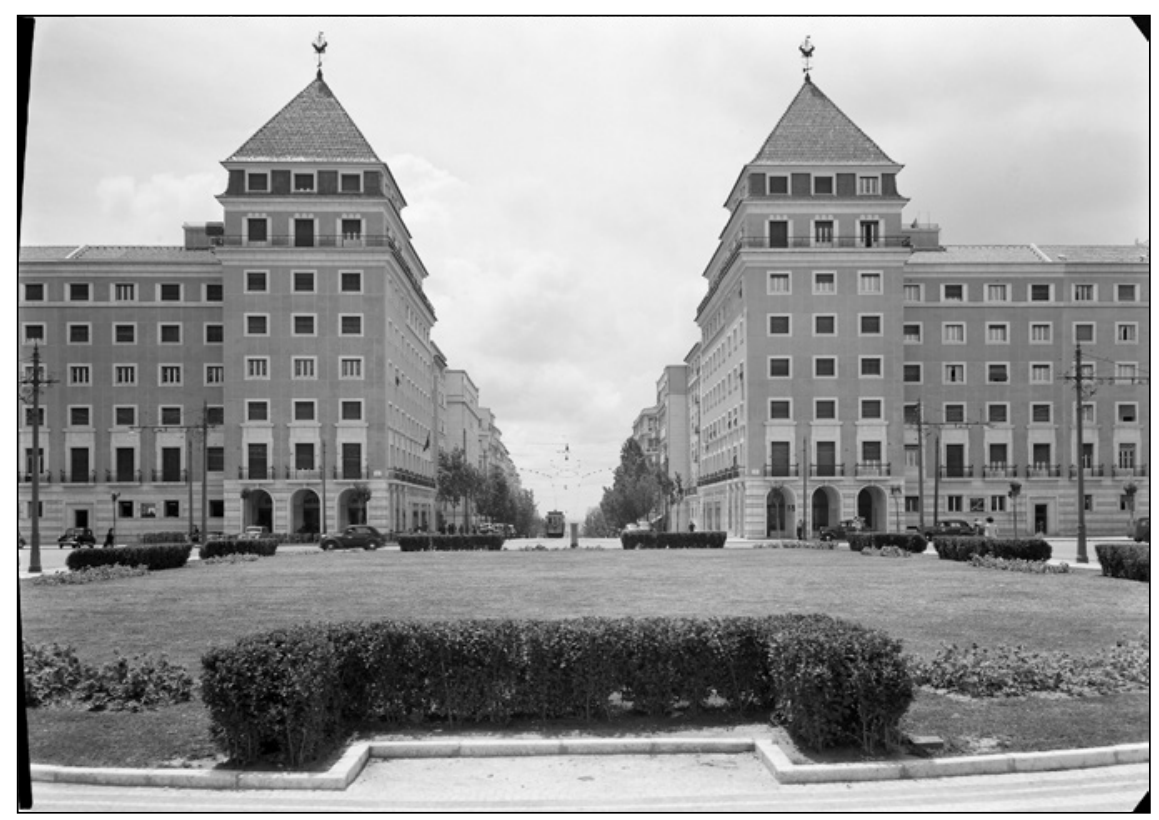

FIGURE 5 Areeiro Neighbourhood, 1941-196o, by arch. Christino da Silva. Photographer:

Horácio Novais.

SOURCE: ART LIBRARY FUNDAÇÃO CALOUSTE GULBENKIAN, CFT164.45118.

suited the views of the leader and its elites. That is why, as has been pointed out by Vieira de Almeida, the monument was never built. ${ }^{118}$

\section{Conclusion}

From the 1930s to the years immediately following the Second Word War, building activity in Portugal had grown exponentially due to the New State's dictatorial nature, its centralized decision-making process, and the minister Duarte Pacheco's charisma and political strength. Pacheco's achievements were even more conspicuous in a country with a great deal to be done, particularly in the field of architecture and urban planning.

However, this exceptional activity in public construction did not give rise to a fascist aesthetics that would have represented a radical political project similar to that of Nazism and Fascism. A mild architectural modernism emerged, but the regime's lack of revolutionary spirit, its attachment to traditionalism

118 See Vieira de Almeida, A Arquitectura no Estado Novo. 
and conservatism, and its resistance to the globalizing forces of modernity 119 acted as a barrier against its fascistization. Meanwhile, state intermediary bodies would guarantee that any kind of fascist revolutionary material form were replaced by a hybrid model which was neither fish nor fowl, neither completely avant-garde nor traditional. From the moment Pardal Monteiro had been replaced by Cottineli Telmo as the 'state architect', a para-fascist architecture seems to have emerged, although not very convincingly. This also shows how the regime drew upon a complex network of personal relationships, in which ideological coherence was never the criterion adopted to determine the path to follow.

Nonetheless, it was during the Pacheco period that an attenuated aesthetic modernism arose. Radical innovation failed to be implemented because the Portuguese Estado Novo was never fascist in its essence, and could not provide the framework of political modernism and a modernist state ${ }^{120}$ within which varieties of aesthetic modernism could thrive. Indeed, to be revolutionary it was not enough to abundantly use the word revolution, a slippery, polysemic word as we can see in the following speech of the chief of the Portuguese Propaganda: 'I come here, lads, to preach the revolution.... The revolution is the corporatist state, the balanced budget's miracle, roads without holes, the new fleet, public works, the new constitution'. He would go on to say that some people would have preferred a fascist leadership style, but Salazar's 'apparent coldness' and 'dynamic serenity,' 'excite us' much more than 'the exuberant Mediterranean gestures of the great Mussolini or the theatrical speeches, astutely orchestrated by Hitler.'121 A quieter, stable, less histrionic dictatorship which banished extremes and anarchy, and set about presiding over a gradual process of modernization restrained by the power of tradition, custom, and the Church, was the alternative modernity proposed by the Estado Novo regime and its supporters.

\footnotetext{
119 António Costa Pinto and Maria Inácia Rezola, 'Political Catholicism, Crisis of Democracy and Salazar's New State in Portugal,' Totalitarian Movements and Political Religions 8, no. 2 (2007): 353-368; Carvalho and Pinto, "The "everyman" of the Portuguese New State during the Fascist Era.'

120 See Griffin, Modernism and Fascism, chapters 7-11.

121 Acção Escolar Vanguarda: Discursos da sessão inaugural e outros documentos (Lisbon: Editorial Vanguarda, 1934).
} 